\title{
Is positive thinking among anthropological constants?
}

\author{
Libor Šimek \\ Ústav antropologie, Př́rodovědecká fakulta, Masarykova univerzita, Vinařská 5, 60300 Brno \\ Received $15^{\text {th }}$ February 2016; accepted $12^{\text {th }}$ April 2016
}

\section{PATŘí POZITIVNÍ MYŠLENÍ MEZI ANTROPOLOGICKÉ KONSTANTY?}

\begin{abstract}
ABSTRAKT Pozitivní psychologie je dnes nejpopulárnějším psychologickým oborem. Ačkoliv se zdá, že výsledky vědeckého výzkumu jasně prokázaly užitečnost pozitivního př́stupu, ne všechny studie jsou tak jednoznačné. V některých studiích se prokázala marnost všeobjímajícího pozitivního př́stupu a dokonce značný benefit vyplývající z pesimismu. Poznatky týkající se našeho evolučního nastavení spíše naznačují, že jedinci s přecitlivělostí k nebezpečí ergo k negativním aspektům svého okolí jsou lépe vybaveni pro přežití. Účelem tohoto článku je porovnat výsledky současného výzkumu spolu s nejnovějšími poznatky $\mathrm{z}$ evoluční psychologie, a tak přispět $\mathrm{k}$ vyrovnanějšímu náhledu na tvrzení pozitivní psychologie.
\end{abstract}

KLÍČOVÁ SLOVA Pozitivní psychologie; esoterika; evoluce; negativní smýšlení; hyperaktivní zařízení na detekci činitelů

ABSTRACT The positive psychology is among currently dynamically evolving psychological approaches. Its 'positive' effects have been verified in research. While some recent research projects suggest that there are limits to the approach. Contrariwise, finding high benefit in the pessimistic thinking. Findings from evolutionary psychology suggest that individuals with oversensitivity to danger could be better adjusted to the environment. It is an overall purpose of this article through a concise overview of and comparison of the present research and evolutionary findings to contribute to its balanced evaluation.

KEY WORDS Positive psychology; esotericism; evolution; negative thinking; HADD (hyperactive agent detection device)

\section{ORIGINS IN FOLK SCIENCE}

Martin E. P. Seligman, a professor at the University of Pennsylvania is considered a founding father of positive psychology. He conducted research to examine his learned helplessness theory. However, positive psychology has its roots in various disciplines and schools of thought. For example, it could be traced to the esoteric preoccupation with an individual well-being. As this connection has often been left out, it is further elaborated on. William James, one of the early psychologists, a religious seeker and a supporter of esoteric ideas (Albanese 2007) distinguished the link between emotions and expression when he observed that emotions came after one physically acted out (Hefferon - Boniwell 2011). James' father was a friend of Ralph Emerson - the founder of transcendentalism. Mary Baker Eddy, the originator of
Christian Science took inspiration from the Emerson's holistic approach and claimed that all illnesses were created by power of negative thinking (Hanegraaff 1996). James in that time remarked (as cited in, Albanese 2007, 416): 'We are just now witnessing a very copious unlocking of energies by ideas in the persons of those converts to 'New Thought,' 'Christian Science,' 'Metaphysical Healing,' or other forms of spiritual philosophy, who are so numerous among us to-day. The ideas here are healthy-minded and optimistic...' James further quoted the claim of the contemporary New Age movement (as cited in, Albanese 2007, 418): 'Pessimism leads to weakness. Optimism leads to power.' For James the mind-cure movement worked as it was supported by experiential results (Albanese 2007). James was a friend of Charles Peirce, the founder of American semiotic tradition. For Peirce beliefs were 'rules for action' (as cited in, 
Albanese 2007, 418). 'Prosperity' teachers such as Napoleon Hill and Dale Carnegie took their inspiration directly from the New Age movement (Albanese 2007). One of the best known authors of popular positive thinking literature - Norman Vincent Peale was influenced by the New Age Movement (Albanese 2007). His book The Power of Positive Thinking has become bestseller (Albanese 2007). Not surprisingly, the founder of the contemporary positive psychology is located in the USA where the New Age movement has been one of the strongest sources of inspiration for the whole society (Ehrenreich 2009). Positive psychology took its inspiration from other psychological disciplines such as from its earlier predecessor: humanistic psychology. This approach centers on empowering individual and emphasizes the importance of the ones' perception of the world around with its focus on positive attributes of human life (Hefferon - Boniwell 2011). While those two disciplines do not seem to be merging, due to their methodological discrepancies, they seem to be largely complementary. Humanistic psychology criticizes positive psychology approach to testing its hypotheses, deeming it as biased to quantitative approach while emphasizing the need to use qualitative methods as well (Hefferon - Boniwell 2011).

\section{AN OVERVIEW OF A PRESENT RESEARCH}

Positive psychology presently strives to become a distinguished field. For instance, The American Psychological Association has 56 branches, and the British Psychological Society acknowledge nine charted areas of psychology, and none of them is reserved to positive psychology. The disagreement exists on if positive psychology should become a separate field, or if it actually permeates all areas of psychology (Hefferon - Boniwell 2011). Clinicians criticized preoccupation with psychopathology. Baumgardner and Crothers (2014) show that up to the date, the research demonstrated that negative emotions tend to suppress immune system and other bodily functions thus body is more susceptible to illness while positive emotions seem to enhance these processes. In addition, people with positive attitudes fare much better than people with negative attitudes (Baumgardner Crothers 2014).

Danner, Snowdon and Friesen (2001) conducted a study on the connection between positive emotions and longevity in the sample of 180 nuns. In such a group, factors are strictly controlled, so the significant factor could be more distinguishable. They analysed autobiographies nuns wrote at the beginning of their vocation, stored in church archives, and discovered significant relationship between longevity and early expression of positive emotions.

Positive psychology is not in the opposition to the classical psychology. It is rather concerned with aspects that have been neglected. Sheldon and King (as cited in 2001, 216) elaborate: 'Positive psychology is thus an attempt to urge psychologists to adopt a more open and appreciated perspective regarding human potentials, motives and capacities.'

\section{RESEARCH FINDINGS ARE CONTRADICTORY}

Contrariwise, Oettingen (2014) warns about a cult of optimism. She quotes PepsiCo research surveying American consumers as part of Pepsi Optimism Project, in 2010, 94\% of surveyed firmly believed that optimism definitely has a positive impact on the world. Both authors, Bandura (1997) and Seligman (1990) seemed to establish that positive expectations increased ones' effort and therefore, the result. Nevertheless, Oettingen and Wadden (1991) conducted a study to confirm such a link on twenty-five obese women enrolled in the weight-loss program. Before the commencement, they were asked how much weight they wanted to lose and how likely they think it would happen. Fantasizing about the future ideal figure was involved. After one year of evaluation, women who had higher expectation lose less than those who pictured themselves more negatively. Oettingen (2014) further asked 117 college students in the introductory psychology class what grade they wished to achieve on the midterm. It was actually two days before the exam. They were asked to complete hypothetical scenarios 'You have already completed test and today is the day that grades are posted' and so on. Some stories were more positive others rather negative. Students were asked to grade them as positive or negative. The results were: more students positively fantasized about the grades the lower they scored and reported studying.

\section{EVOLUTIONARY MAKEUP IS NOT READY FOR POSITIVITY}

Ehrenreich (2009) considers prevalent positive thinking in the USA a mass delusion. She argues through that we get detached from our emotions and detach themselves of objective facts, especially those we do no like. She mentioned that realism - to the point of defensive pessimism is a prerequisite not only for human survival but for all animal species. She states: 'Watch almost any wild creature for a few moments and you will be impressed, above all, by its vigilance' (as cited in, Ehrenreich 2009, 196).

Interestingly, this is in accordance with the theory proposed by a psychologist Justing Barret (2000) which was originally devised to supply reasons of why people believe in supernatural beings. Barrett (2000) coined the acronym HADD (hyperactive agent detection device) to describe the cognitive processes that assists us in recognizing agents (actually, animacy) and distinguishes them from non-agents. This mental 'device' is hyperactive or hypersensitive, in that under specific conditions, it is triggered by very minimal cues. We see faces in the clouds and recognize predators in rustling bushes because such ambiguous perceptions easily trigger the postulation of agency. In short, in the past, one who was not endowed with such an oversensitivity to danger did not have high hopes to survive. Surprisingly, research findings confirmed that repeatedly imagining the act of eating a deli- 
cious food actually reduces our actual consumption of that food (Morewedge - Huh - Vosgerau 2010). Possibly, fooling our brain that we have already achieved something could deprive it for the energy to accomplish it. This was endorsed by a following study (Kappes - Kappes - Oettingen, as cited in Oettingen 2014). Students were to read a passage on the situation when they caught their partner cheating on them, and then they were given a test which comprised of series of words and word-like collections of letters (some nonsensical). They were to affirm if the letters appeared real. Some of the letters were related to violence. Then, they were given the second part of the story where they imagined they took revenge for their disgrace. As a consequence of such a process of imagination, they were able to identify more slowly words related to revenge. As the goal had been already attained in the mind - more positive students' fantasies about exacting revenge - slower identifying words related to violence and aggression. It appears that mind did not want to deal with it anymore.

In the other experiment, Oettingen, Pak and Schnetter (2001) had 168 female students in two universities rated interpersonal wish on the scale to $100 \%$. They were to express how they are likely to achieve it. Each of them was given four sets of positive words such as having more time for each other', 'feeling loved'... One group was to mentally contrast two positive and two negative reality key words and alternating between two. The second group had only success words. A third group fantasized about possible obstacles, and a fourth group elaborated first on negative and positive key words. Immediately afterwards, they were asked about the level of energy and activity and two weeks after the experiment they were sent a questionnaire to list all actions they took based on their wishes. Interestingly, if their thought was based on the past success experience, then contrasting energized them enough to take action, while students who had mentally contrasted judged a success (based on the past experience) unlikely, felt less energized and took less action. It seems that it is feasible to pursue not just every dream but a dream that seems feasible.

Oettingen (2014) further recommends comparing the reality with the wished reality and then to contrast both. For that process, she devised a method of sequential thinking Woop: wish, outcome, obstacle, plan. While, Norem (2001) praises the positive power of negative thinking, she argues that defensive pessimism is a strategy that helps defensive pessimists to work through their anxious thoughts so that they may achieve their goals. Norem (2001) has demonstrated that when defensive pessimists are stripped off their pessimism by being led to look on the bright side of life, their performance on tasks plummets. Their pessimism actually makes them good in planning (by going through the worst scenarios, etc.) as they cannot plan well until they acknowledge and take control of their anxiety. Tolerance to negative feelings these pessimists have, in fact, could have some value as to byproducts of delaying gratification; learning from bad experiences; assessing risks...

\section{CONCLUSIONS}

Oettingen (2014) argues that some of her research was not allowed to be published in peer-reviewed journals as her reviewers considered findings hideous or irrelevant. Similarly, as the research program in the USA prefers more studies on social advantage of religion than other religious research agendas due to the political climate, it is a viable possibility that the same occurs with the research on positivity due to a pervading cult of optimism. The results from this research could remind not only positive psychologists that no size fits all. Positivity should be utilized, and benefits of positive approach should be valued. While at the same time it should not be overpriced. As Norem (2001) emphasizes defensive pessimists do not have to be cured of their defensive pessimism. It is actually a cure for their anxiety. One, living in the society that stresses out the responsibility to be $\mathrm{OK}$ and to stay in a positive frame of mind at all times, could start feeling abnormal or become depressed. Which is just contrary to what positive approach claims to accomplish. The intention of this article is to alleviate extremes. During the history, left-handed people were ostracized. Similarly, there exists a viable possibility that pessimists could get in the similar position. Furthermore, all pervasive positivist thinking could lead to dire negative consequences. Ehrenreich (2009) points out that the largest 'empirical' study of the American nation, where the positivity is a programmed frame of mind, shows how exclusively positive approach brought it to the brink of economic depression. It is pertinent to notice that Norman Vincent Peale; the main promoter of positive thinking ended bankrupt and if it was not one of his admirer's concern, he would end up on the street. Further studies should focus on viable differences between a useful positive frame of mind and a potentially useless positive frame of mind. Furthermore, studies should not predominantly focus on working with western undergraduate students. Cross-cultural studies are highly needed to evaluate positivity in the anthropological context. There is still a conceivable possibility that thinking positively is not among anthropological constants.

\section{REFERENCES}

Albanese, C. L. (2007): A republic of mind and spirit: a cultural history of American metaphysical religion. Yale: Yale University.

Barrett, Justin L. (2000): Exploring the natural foundations of religion. Trends in Cognitive Sciences, 4, 29-34.

Bandura, A. (1997): Self-efficacy: The exercise of control. New York: W.H. Freeman.

Baumgardner, S. - Crothers, M. (2014): Positive Psychology. Essex: Pearson.

Danner, D. - Snowdon, D. - Friesen, W. (2001): Positive emotions in early life and longevity: Findings from the nun study. Journal of Personality and Social Psychology, 80, 804-813.

Ehrenreich, B. (2009): Bright-sided: how the relentless promotion of positive thinking has undermined America. New York: Metropolitan Books.

Hanegraaff, J. W. (1996): New Age Religion and Western Culture. New York: Brill.

Hefferon, K. - Boniwell, I. (2011): Positive Psychology: Theory, Research and applications. New York: Open University Press.

Morewedge, C. K. - Huh, Y. E. - Vosgerau, J. (2010): Thought for food: Imagined consumption reduces actual consumption. Science, 330, 1530-1533. 
Norma, J. (2001): The positive power of negative thinking. New York: Basic Books.

Oettingen, G. - Wadden, T.A. (1991): Expectation, Fantasy, and Weight loss: Is the Impact of Positive Thinking Always Positive? Cognitive Therapy and Research, 15, 2, 167-175.

Oettingen, G. - Pak, H. - Schnetter, K. (2001): "Self-Regulation of Goal Setting: Turning Free Fantasises About the Future into Binding Goals. Jour nal of Personality and Social Psychology, 80, 736-753.

Oettingen, G. (2014): Rethinking positive thinking: inside the new science of motivation. New York: Penguin.
Seligman, M. E. P. (1990): Learned optimism. New York: Pocket Books. Sheldon, K. M. - King, L. (2001): Why positive psychology is necessary. American Psychologist, 56, 216-217.

\section{AUTHOR}

The author graduated from Applied Psychology at University of Derby, UK and from Religious studies at Masaryk University, Brno. 